\title{
Bimbingan Teknis Pembuatan Kampas Rem Cakram Berbahan Komposit Polimer Untuk Sepeda Motor
}

\author{
Aminur*1, La Hasanudin², Salimin ${ }^{3}$, Abd. Kadir ${ }^{4}$, Raden Rinova Sisworo ${ }^{5}$, Citra Yurnidarsyah ${ }^{6}$ \\ 1,2,3,4,5,6 Program Studi Teknik Mesin, Program Pendidikan Vokasi, Universitas Halu Oleo \\ *e-mail: aminur@uho.ac.id ${ }^{1}$, hasanudin.kia@gmail.com ${ }^{2}$, Ir.salimin@gmail.com ${ }^{3}$, Kadirmt30@gmail.com ${ }^{4}$, \\ raden.rinova@uho.ac.id ${ }^{5}$, citraysyah@gmail.com ${ }^{6}$
}

\begin{abstract}
Brake pads are one of the most vital components in a vehicle that functions to slow down and even stop the speed when there is a threat of accident due to the uncontrolled speed of the vehicle by the driver. Brake pads on the market are generally made of asbestos, which has disadvantages including not being environmentally friendly. The purpose of implementing technical guidance on the manufacture of motorcycle disc pads is to provide knowledge to students of the Automotive Department of SMK 2 Kendari and D3 Mechanical Engineering students of the Vocational Education Program, about how to use fiber and coconut shell materials as alternative materials for disc brake pads. This service also encourages students' creativity and business interest in utilizing coconut shell natural materials as material for brake pads in vehicles, especially motorcycle brake pads which must be replaced periodically with new ones. The partner of this activity is the Shaqueela Barakati workshop, Anduonohu Village. Through this service program, it is hoped that new entrepreneurs who are innovative, creative and competitive in increasing competence will be created independently. This activity took place very effectively and efficiently, marked by the enthusiasm of students and students in preparing materials to carry out the manufacture of brake lining products.
\end{abstract}

Keywords: guidance, brake lining, fiber, and coconut shell

\begin{abstract}
Abstrak
Kampas rem merupakan salah satu komponen yang sangat vital dalam sebuah kendaraan yang berfungsi memperlambat bahkan menghetikan kecepatan pada saat terjadi ancaman kecelakaan akibat laju kendaraan yang tidak terkontrol oleh pengendara. Kampas rem yang beredar di pasaran umumnya terbuat dari bahan asbestos yang memiliki kekurangan diantaranya tidak ramah lingkungan. Tujuan dari pelaksanaan bimbingan teknis pembuatan kampas cakram sepeda motor adalah untuk memberikan pengetahuan kepada siswa Jurusan Otomotif SMK 2 Kendari dan Mahasiswa D3 Teknik Mesin Program Pendidikan Vokasi, tentang bagaimana memanfaatkan bahan serat dan tempurung kelapa sebagai bahan alternatif kampas rem cakram. Pengabdian ini juga mendorong kreativitas serta minat berusaha siswa dan mahasiswa dalam memanfaatkan bahan alam tempurung kelapa sebagai bahan kampas rem pada kendaraan khususnya kampas rem sepeda motor yang secara berkala harus diganti dengan yang baru. Mitra kegiatan ini adalah bengkel Shaqueela Barakati Kelurahan Anduonohu. Melalui program pengabdian ini diharapkan terwujudnya wirausaha baru yang inovatif, kreatif dan berdaya saing dalam meningkatkan kompetensi secara mandiri. Kegiatan ini berlangsung sangat efektif dan efisien ditandai dengan antusiasme siswa dan mahasiswa dalam mempersiapakan bahan hingga melaksanakan pembuatan produk kampas rem.
\end{abstract}

Kata kunci: bimbingan, kampas rem, sepeda motor, tempurung kelapa

\section{PENDAHULUAN}

Saat ini penggunaan sepeda motor sebagai alat transportasi semakin meningkat. Sepeda motor sebagian kalangan dianggap paling efektif dan efisien ditengah keterbatasan infrastruktur jalan dan kepadatan pengendara roda empat. Beberapa alasan yang menjadikan sepeda motor primadona dari desa hingga perkotaan yang berskala modern sekalipun adalah karena sepeda motor dapat mengakses jalan-jalan sempit, dapat digunakan untuk medan yang berat/rusak, ketepatan jarak tempuh, dapat menghindari macet dan harga relatif terjangkau. Melihat keunggulan yang dimiliki oleh sepeda motor maka kemudian usaha manufaktur dan produksi sepeda motor pun kian melonjak tajam. Seiring dengan meningkatnya produksi sepeda motor maka kemudian salah satu komponen yang menjadi perhatian khusus adalah rem yang merupakan komponen utama dari segi keselamatan pengendara. Setiap kendaraan memiliki dua sistem pengereman yang berada di depan dan di belakang. Umumnya rem pada roda depan 
menggunakan sistem pengeraman kampas cakram dan bagian belakang menggunakan sistem tromol, akan tetapi sebagian sepeda motor saat ini kedua-duanya menggunakan sistem pengereman kampas cakram. Setiap jenis mesin mengunakan bahan rem yang berbeda (M \& Ibhadode, 2006). Kelebihan rem cakram dibandingkan dengan rem tromol adalah daya pengeremannya yang lebih maksimal (Upara \& Laksono, 2019). Kampas rem yang beredar di pasaran kebanyakan dari bahan asbestor yang tidak ramah lingkungan karena dapat meninmbulkan Karsinogen (sifat yang dapat mengedap dan merusak terutama organ paru-paru) (Aigbodion, Akadike, Hassan, Asuke, \& 0, 2010) (Yudhanto, Dhewanto, \& Yakti, 2019). Residu pengereman yang berukuran partikel kecil akan tersimpan sebagian ditromol bahkan dibagian plat cakram sehingga ketika terjadi perbaikan sistem pengeraman akan terhirup oleh manusia. Peraturan pemerintah, menyarankan kesadaran masyarakat untuk melestarikan lingkungan hidup melalui program penggunaan material yang didesain ramah lingkungan seperti penggunaan serat dan partikel penyusun kampas dari bahan yang bersifat alamiah. Berdasarkan kecelakaan lalu lintas yang disebabkan kendaraan menunjukkan bahwa komponen seperti rem, kemudi, ban, as depan, as belakang, lampu depan, lampu belakang yang merupakan faktor utama penyebab kecelakaan adalah komponen rem yang tidak berfungsi dengan baik (Herawati, 2012). Pemanfaatan partikel tempurung kelapa sebagai penghambat laju keausan bahan gesek non asbes karena tempurung kelapa tersebut memiliki karakteristiek kekerasan, dan kerapatannya tinggi, serta serapan airnya rendah (Morshed \& Haseeb, 2004). Hal ini juga didukung oleh sektor sumber daya bahan baku kelapa yang melimpah, tetapi belum dapat mendongkrak perekonomian masyarakat (Maherawati \& Suswanto, 2020).

Serbuk tempurung kelapa dapat dimanfaatkan sebagai serat penguat bahan friksi nonasbes (Kiswiranti, Sugianto, Hindarto, \& Sutikno, 2009). Dalam penelitian ini, komposisi 20\%dan $30 \%$ serbuk tempurung kelapa ditemukan yang paling optimum untuk parameter kekerasan dan keausan. Bahan friksi dengankomposisi 20\% memiliki kekerasan sebesar 77,5 kgf.mm-2 dan keausan sebesar 28,25 mm2/kg. Bahan friksi dengan komposisi $30 \%$ serbuk tempurung kelapa mempunyai kekerasan sebesar 58,8 kgf.mm-2 dan keausan sebesar $34 \mathrm{~mm} 2 / \mathrm{kg}$. Untuk dapatdiaplikasikan pada sepeda motor, desain sampel disesuaikan dengan spesifikasi kampas rem sepeda motor. Proses pembuatan biokomposit polimer serat untuk aplikasi kampas rem dengan menggunakan bahan serat buah pinang ditambahkan serbuk alumina dengan bahan perekat resin poliester (Aminur, Hasbi, \& Gunawan, Proses Pembuatan Biokomposit Polimer Serat Untuk Aplikasi Kampas Rem, 2015). Komposit polimer dari bahan alam telah banyak dilakukan, salah satunya adalah memanfaakan serat rami dan serbuk tempurung kelapa sebagai penguat dengan perekat resin poliester dalam pembuatan biokomposit polimer untuk aplikasi kampas rem sepeda motor (Aminur, Samhuddin, \& Sudia, Biokomposit Polimer Berpenguat Serat Rami dan Partikel Tempurung Kelapa Sebagai Material Kampas Rem Sepeda Motor, 2019).

\section{METODE}

Adapun medel pelaksanaan kegiatan pengabdian secara keseluruhan meliputi:

1. Persiapan program;

Pada tahapan program dipersiapakan meliputi waktu pelaksanaan, tempat pelaksanan dan peserta yang dilibatkan serat alat dan bahan yang digunakan dalam kegiatan pengabdian. Kegiatan ini dilakukan selama 3 bulan mulai bulan September sampai dengan Desember 2020 di Bengkel Shaqueela Barakati Kelurahan Anduonohu Kecamatan Poasia Kota Kendari.

2. Penyiapan alat dan bahan;

Alat yang digunakan pada program pengabdian ini adalah satu set cetakan kampas rem dan alat tekan serta alat bantu lainnya. Bahan yang digunakan terdiri dari serat rami dan tempurung kelapa. 




Gambar 1. Alat cetak dan tekan kampas rem

Adapun bahan yang digunakan meliputi resin poliester, serbuk tempurung kelapa, serat, mirror glaze dan wadah untuk mencampur bahan.

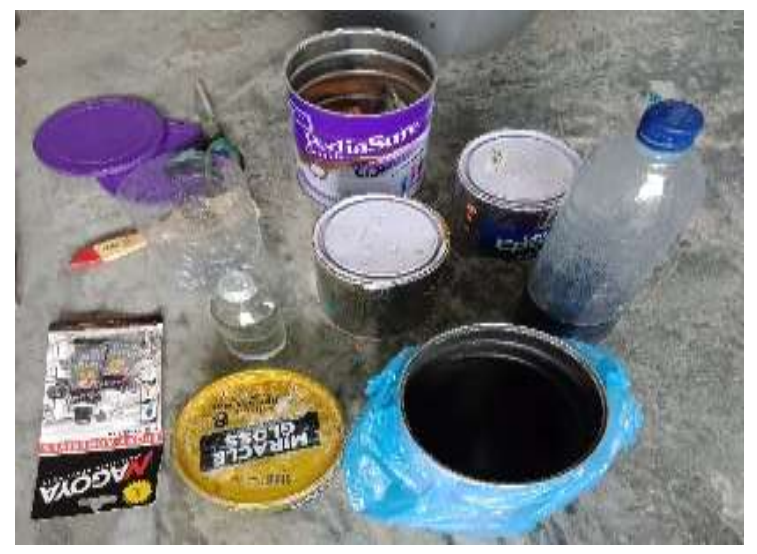

3. Sosialisasi

Gambar 2. Bahan-bahan

Tujuan sosialisasi dilaksanakan dalam rangka memberikan informasi terkait kegiatan pengabdian yang akan diberikan kepada mitra. Pada bagian ini tim pengabdian berdiskusi dengan mitra untuk mengetahui permaslalahan yang dihadapi dan mencari solusi untuk menatasi permasalahan tersebut. Mitra menyambut baik dengan adanya kegiatan pengabdian ini dengan menyiapakan tempat pertemuan, dan berpartisipasi merumuskan tahapan pelaksanaan kegiatan serta berkomitmen mengikuti rangkaian kegiatan sampai selesai. Selain itu juga peserta diberikan pengetahuan bagaimana memanfaatakan bahan-bahan serat untuk bahan komposit khususnya kampas rem.

4. Partisipatif

Pada tahapan ini, kegiatan dilaksankan dengan pendekatan yang berorientasi kepada upaya peningkatan peran serta masyarakat secara langsung dalam berbagai proses dan pelaksanaan. Peserta dilibatkan langsung dalam kegiatan proses pembuatan kampas.

5. Pendampingan

Pada tahap ini dilaksanakan pendampingan aplikatif secara langsung kepada seluruh peserta dalam rangka melaksanakan pembuatan kampas rem.

6. Evaluasi

Tahapan valuasi merupakan tahap akhir pengabdian program masyakat dimana tahapan yang telah dilaksanakan dievaluasi tingkat keberhasilannya. Tujuan metode evaluatif dilakukan adalah untuk menentukan tingkat capaian atas sasaran yang ingin didapatkan dalam setiap program kegiatan. 


\section{HASIL DAN PEMBAHASAN}

Pelaksanaan kegiatan pengabdian dimulai dengan memperkenalkan bahan dan alat yang digunakan untuk memfabrikasi kampas rem. Bahan-bahan yang digunakan berasal dari alam sehingga tidak menimbulkan bahaya terhadap lingkungan dan keberadaan bahan tersebut melimpah adanya serta proses untuk mendapatkan juga lebih mudah. Setelah memperkenalkan bahan bahan-bahan dan alat yang digunakan maka langkah selanjutnya adalah melaksanakan bimbingan teknis tentang cara membuat kampas rem. Kampas rem yang dibuat pada pelaksanaan bimbingan teknis ini adalah kampas rem cakram.

\subsection{Penyajian Bahan}

Serat yang digunakan adalah serat Rami yang masih dalam bentuk lembaran/helai serat. Lembaran serat dipotong-potong dengan ukuran antara 1-3 mm, sedangkan tempurung kelapa terlebih dahulu dibakar menjadi arang dan kemudian dibuat serbuk dan dilakukan pengayakan dengan ukuran partikel lolos 80-100 mesh. Setelah serat dan tempurung kelapa diolah, kemudian dikeringkan kedalam oven dengan suhu $110^{\circ} \mathrm{C}$ selama 1 jam. Tujuan pengovenan ini adalah untuk mengurangi kadar air yang ada pada kedua bahan serat dan serbuk tempurung kelapa.



Gambar 3. Penyajian serat dan serbuk tempurung kelapa

\subsection{Pelaksanaan Bimbingan Pembuatan Kampas Rem Cakram}

Serat Rami dan serbuk Tempurung Kelapa yang telah disiapkan, kemudian ditimbang dengan komposisi campuran serat 30\%, serbuk 30\% dan resin poliester $40 \%$. Untuk menentukan berat masing-masing kebutuhan bahan maka terlebih dahulu dilakukan perhitungan dengan menggunakan fraksi volume serat. Dari hasil perhitungan tersebut didaptkan berat serat, berat serbuk tempurung kelapa dan berat resin polester yang dbutuhkan.



Gambar 4. Proses penimbangan bahan

Setelah seluruh bahan ditimbang kemudian resin dan hardener dicampur dengan perbandingan 98:2\%. Proses pencampuran resin dan hardener \pm 2 menit. Setelah tercampur sempurna, dilanjutkan dengan memasukkan serat dan serbuk kedalam wadah campuran resin. Proses pencampuran ketiga bahan ini harus dilakukan secara sempurna dimana seluruh 
permukaan serat dan serbuk harus dipastikan terbasahi semua oleh cairan resin. Proses pencampuran ini berlangsung 2-5 menit tergantung banyaknya komposisi campuran.

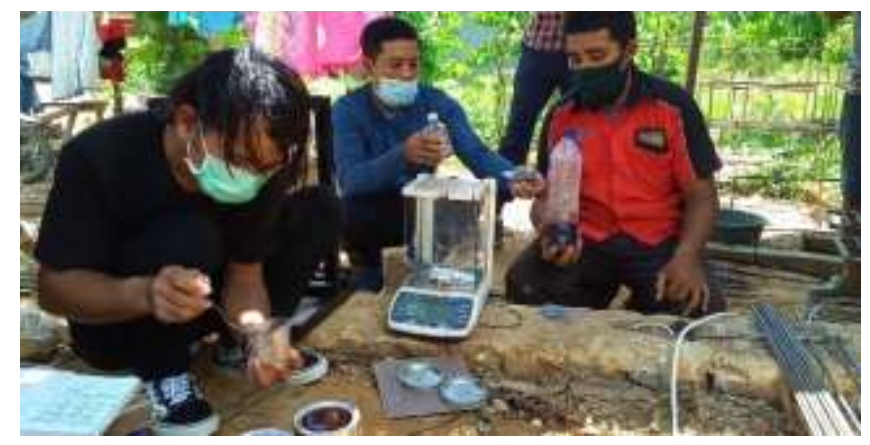

Gambar 5. Pencampuran serat, serbuk dan resin

Adonan campuran serat, serbuk dan resin ditiriskan kedalam cetakan kampas. Cetakan ini terdiri dari 3 bagian yaitu bagiang tutup, alas dan puch, berbentuk menyerupai kampas rem. Cetakan tersebut terbuat dari bahan kayu keras yang dilapisi besi strip pada bagian sisi-sisinya. Pada bagian alas cetakan dilapisi lem Dextone Epoxy Adhesives yang berfungsi sebagai perekat antara lapisan plat cakram dan adonan bahan kampas.

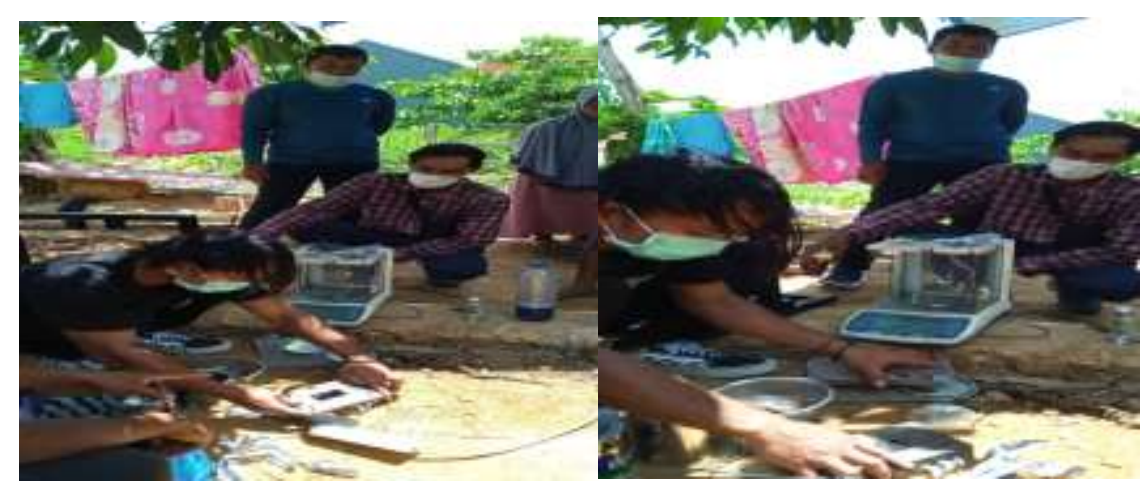

Gambar 6. Proses penuangan adonan campuran bahan

Campuran yang telah ditiriskan kedalam cetakan kampas rem, kemudian ditekan dengan menggunakan alat pres. Pengepresan dilakukan selama 3-10 menit. Tujuan pengepresan agar serat, serbuk dan resin mengikat secara sempurna dan padat.

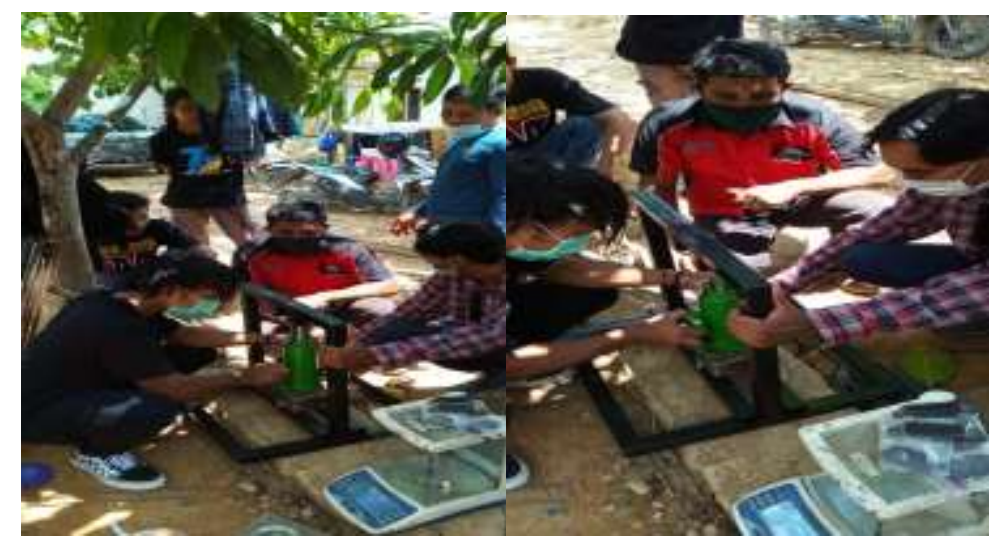

Gambar 6. Proses pengepresan cetakan 
Setelah bahan kampas rem dipres, dilanjutkan proses pelepasan produk kampas dari cetakannya dan produk ini dikeringkan selama waktu tertentu \pm 60 menit pada kondisi suhu ruang $\left(25^{\circ} \mathrm{C}-29^{\circ} \mathrm{C}\right)$.

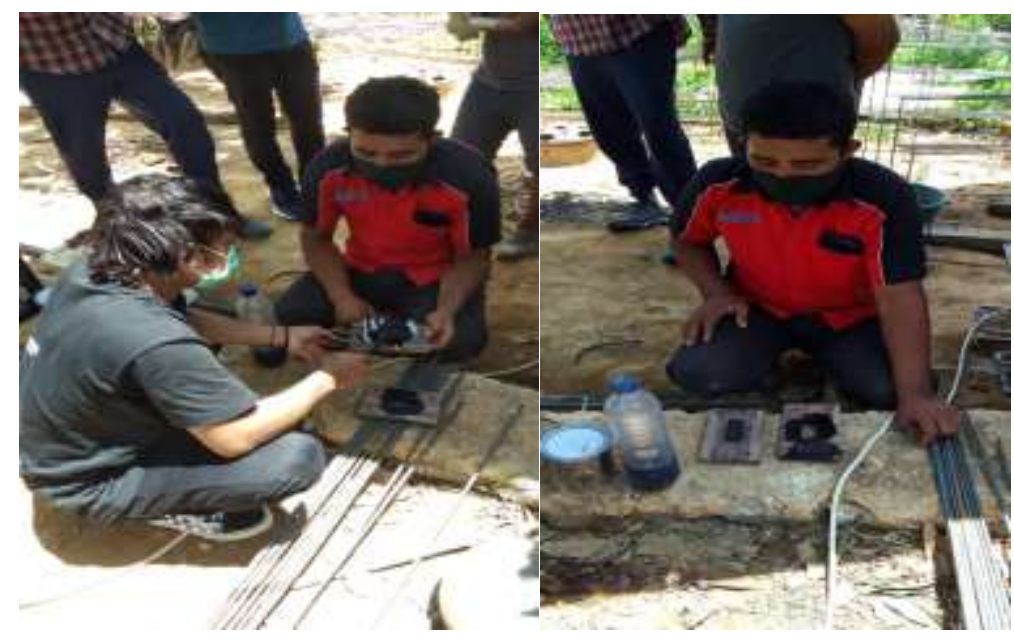

Gambar 7. Proses pelepasan cetakan

\section{KESIMPULAN}

Kesimpulan dari kegiatan yang telah dilaksanakan adalah sebagai berikut:

1. Kegiatan yang dilaksanakan direspon baik oleh peserta karena selama ini kampas rem yang merupakan komponen terpenting pada kenderaan khususnya sepeda motor ternyata dibuat dengan alat yang sederhana dan bahan bakunya juga dapat diperoleh dengan mudah dan tersedian banyak di alam.

2. Selama kegiatan berlangsung, peserta antuasias mengikuti rangkaian kegiatan sampai selesai dan peserta dapat memahami seluruh tapan pelaksanaan kegiatan pengabdian, hal ini dilihat dari keseriusan peserta berpartisipasi secara langsung dalam pelaksanaan pembuatan kampas rem.

3. Kegiatan pengabdian ini menghasilkan produk kampas rem dengan memanfaatkan bahanbahan alam yang tersedia di kota Kendari.

\section{UCAPAN TERIMA KASIH}

Penulis mengucapkan terima kasih dan apresiasi setinggi-tingginya kepada Program Pendidikan Vokasi Universitas Halu Oleo yang telah memberikan pembiayaan dalam pelaksanaan kegiatan Pengabdian Kepada Masyarakat melaui dana internal Vokasi. Ucapan terima kasih juga kepada mitra kami, Bengkel Shaqueena Barakati sehingga seluruh rangkaian kegiatan pengabdian ini dapat berjalan dengan kodusif walaupun dalam suasana di tengah pandemi wabah Covid 19.

\section{DAFTAR PUSTAKA}

Aigbodion, V. S., Akadike, U., Hassan, S. B., Asuke, F., \& O, A. J. (2010). Development of Asbestos Free Brake Pad Using Bagasse. Tribology in industry, 32(1), 12-18.

Aminur, A., Hasbi, M., \& Gunawan, Y. (2015). Proses Pembuatan Biokomposit Polimer Serat Untuk Aplikasi Kampas Rem. Jakarta: Prosiding Semnastek Muhammadiyah.

Aminur, A., Samhuddin, S., \& Sudia, B. (2019). Biokomposit Polimer Berpenguat Serat Rami dan Partikel Tempurung Kelapa Sebagai Material Kampas Rem Sepeda Motor. Malang: Prosiding SENIATI. 
Herawati. (2012, Maret 2014). Karakteristik Dan Penyebab Kecelakaan Lalu Lintas Di Indonesia Tahun 2012. Warta Penelitian Perhubungan, 26(3), 133-142.

Kiswiranti, D., Sugianto, S., Hindarto, N., \& Sutikno. (2009). Pemanfaatan Serbuk Tempurung Kelapa Sebagai Alternatif Penguat Bahan Friksi Non-Asbes Pada Kampas Rem Sepeda Motor. Jurnal Pendidikan Fisika Indonesia, 5(1), 62-66.

M, D. I., \& Ibhadode, A. A. (2006). Determination of Optimum Manufacturing Conditions for Asbestos-free Brake Pad using Taguchi Method. Nigerian Journal of Engineering Research and Development, 5(4), 1-8.

Maherawati, \& Suswanto, I. (2020, September). Teknologi Tepat Guna Pemurnian Minyak Kelapa Tradisional Di Desa Mengkalang Jambu Kabupaten Kubu Raya Kalimantan Barat. DINAMISIA: Jurnal Pengabdian Kepada Masyarakat, 4(3), 482-489. doi:DOI: https://doi.org/10.31849/dinamisia.v4i3.3766

Morshed, M. M., \& Haseeb, A. M. (2004). Physical and Chemical Characteristics of Commercially Available Brake Shoe Lining Materials: A Comparative Study. Bangladesh University of Engineering and Technology: Dhaka: Materials and Metallurgical Departement.

Upara, N., \& Laksono, T. B. (2019, Januari). Analisa Komparasi Kualitas Produk Kampas Rem Cakram Antara Original Dengan After Market. Jurnal ASIIMETRIK: Jurnal Ilmiah Rekayasa \& Inovasi, 1(1), 26-33. Retrieved Januari 6, 2021

V, S. A., Akadike, U., Hassan, ,. S., Asuke, F., \& Agunsoye, J. O. (2010). Development of Asbestos Free Brake Pad Using Bagasse. Tribology in industry, Volume (32 No. 1), 11-18.

Yudhanto, F., Dhewanto, S. A., \& Yakti, S. W. (2019, Oktober). Karakterisasi Bahan Kampas Rem Sepeda Motor Dari Komposit Serbuk Kayu Jati. Jurnal Quantum Teknika, 1(1), 19-27. doi:DOI: 10.18196/jqt.010104 